УДК 349.3:364

DOI https://doi.org/10.32837/apdp.v0i85.1877

Л. П. Шумна, К. В. Денисенко, А. С. Бессараб

\title{
ПРАВОВЕ РЕГУЛЮВАННЯ СОЦІАЛЬНИХ ПРАВ ЗАСУДЖЕНИХ ДО ПОЗБАВЛЕННЯ ВОЛІ
}

Постановка проблеми. Важливою ознакою соціальної держави є ефективна та дієва національна система соціального захисту населення, яка функціонує на основі продуманої державної соціальної політики, забезпечує гарантований добробут та гідний рівень життя усіх верств населення. Особливу актуальність у наш час отримала проблематика реалізації соціальних прав засуджених до позбавлення волі. Законодавчі прогалини та колізії, закритість кримінально-виконавчої системи, обмеженість державних гарантій тощо призводять до порушення соціальних прав засуджених.

3 огляду на зазначене посилення уваги до питань дотримання та захисту соціальних прав і свобод осіб, засуджених до позбавлення волі в Україні, сьогодні є важливим завданням.

Аналіз останніх досліджень і публікацій. Загальнотеоретичні та практичні питання нормативно-правового забезпечення прав, зокрема соціальних, засуджених прямо чи опосередковано розглядались у працях таких вітчизняних учених, як О.Г. Гончаренко, О.В. Лисодєд, В.О. Човган, Л.П. Шумна, І.С. Яковець та інші. Водночас сучасні стрімкі процеси, пов'язані з реформуванням соціального та кримінально-виконавчого законодавства, необхідністю визнання й дотримання прав людини створюють потребу додаткових наукових досліджень в окресленому напрямі.

Метою статті є аналіз переваг та недоліків сучасного стану правового регулювання соціальних прав засуджених до позбавлення волі.

Виклад основного матеріалу. Стрімкі сучасні євроінтеграційні процеси, які відбуваються поряд зі змінами політичного устрою, розвитком інституту прав і свобод людини, гуманізацією суспільства та чинного законодавства, збільшенням частки громадян, котрі потребують соціального захисту та підтримки, суттєво підвищують вимоги до держави за обсяг, якість та рівень її діяльності, актуалізуючи роль та функціональне призначення законодавця в частині модернізації державної соціальної політики та вироблення правових підвалин ефективної реалізації соціальних прав окремих індивідів, уразливих і специфічних груп, зокрема засуджених до позбавлення волі.

У цьому контексті видається доцільною думка П. Петровського про те, що «відсутність наукової методології зумовлює спонтанні, безпосередні реагування на проблемніявища» $[1, \mathrm{c.} 118]$. Для розв'язання цих таінших суміжних проблемі протиріч постає необхідність наукового дослідження теоретичних конструкцій таких дефініцій, як «правалюдини», «соціальніправа» та «засуджений» удоктринальному сенсі.

Зауважимо, що попри суттєвий розвиток науки, й донині категорія «соціальні права засуджених до позбавлення волі» не набула належного теоретичного та прикладного осмислення. Переконані, що належне теоретичне осмислення базо-

(ㄷ Л. П. Шумна, К. В. Денисенко, А. С. Бессараб, 2020 
вих понять дослідження допоможе спрямувати практичний складник наявної проблематики у правильне русло.

Наразі найбільш загальноприйнятною думкою щодо змістовного наповнення поняття «права людини» є таке: «це певні можливості (надбання), необхідні для існування та розвитку особи, які визнаються невід'ємними, мають бути загальними та рівними для кожного, забезпечуватись і захищатись державою в обсязі міжнародних стандартів» [2, с. 92].

Відповідно до Великого юридичного словника «соціальні права людини - це сукупність конституційних прав людини (або тільки громадян конкретної держави), котрі дають йому можливість претендувати на отримання від держави (за визначених умов) матеріальних благ. До соціальних прав віднесено право на соціальне забезпечення, право на освіту, право на охорону здоров'я та медичну допомогу, право на житло» [3, с. 708].

В. Левицька переконує, що «соціальні права - права, на які людина має безпосереднє право, що виражається в можливості набуття соціальних благ, володінні, користуванні й розпорядженні ними та їх захисті або вчиненні певних дій у цій сфері, а також у забезпеченні належних соціальних умов життя шляхом гарантування та забезпечення цих прав із боку держави» [4, с. 21].

Показово, що в чинному законодавстві України відсутнє визначення поняття «соціальні права».

Відповідно до Кримінально-процесуального кодексу України, засудженим у кримінальному провадженні є обвинувачений, обвинувальний вирок суду щодо якого набрав законної сили [5].

Варіант, запропонований у Великому тлумачному словнику української мови, визначає засудженого як «людину, яку засудили до якої-небудь міри покарання» [6, с. 426].

Доцільно зауважити, що набуття правового статусу засудженого до позбавлення волі супроводжується наявністю певних специфічних відмінностей та особливостей, порівняно з іншими громадянами, в низці сфер суспільного життя, що чітко регламентовано чинним національним кримінально-виконавчим законодавством.

Поняття «правового статусу засуджених» Ю. А. Чеботарьова окреслює як закріплену нормами різних галузей права сукупність прав, законних інтересів та обов’язків, котрі визначають і характеризують статус засудженого під час відбування ним покарання. На прикладі засуджених до позбавлення волі автор дає такі визначення складових елементів, які формують зміст правового статусу засудженої особи. На її думку, права засуджених до позбавлення волі - це врегульовані законом реальні можливості певної позитивної поведінки й користування соціальними благами, націленими на задоволення особистих потреб та інтересів, досягнення мети виправлення й ресоціалізацію засуджених, забезпечення яких трансформується у правовий обов'язок адміністрації кримінально-виконавчих установ [7, с. 11-12]

Підсумок вищезазначеного та власні напрацювання автора дозволяють визначити ознаки соціальних прав засуджених:

- гарантованість - соціальні права засуджених, закріплені в національних та міжнародних нормативно-правових актах; 
- вони слугують засобом задоволення життєвих потреб на рівні, не нижчому, ніж розмір прожиткового мінімуму, встановленого законом;

- реалізуються в добровільному порядку, за відсутності примусу;

- серцевиною слугують наявність соціальних ризиків та/або складних життевих обставин та/або страхового випадку, причому незалежно від часу їх виникнення - до ув'язнення чи після;

- обсяг соціальних прав засуджених, як правило, варіюється із тривалістю страхового стажу та обсягу отримуваного заробітку;

- можуть реалізовуватись як на регулярній основі, так і на тимчасовій;

- фінансування витрат на реалізацію соціальних прав засуджених здійснюється за кошт Державного бюджету України та інших, не заборонених чинним законодавством, джерел.

Таким чином, соціальні права засуджених до позбавлення волі - це система прав, які закріплені в національних та міжнародних нормативно-правових актах, спрямовані на нейтралізацію складних соціально-життєвих обставин та/або забезпечення рівня життя в обсязі, не менше прожиткового мінімуму, за умови настання соціальних ризиків, а також належного функціонування людського організму громадян, котрі визнані в судовому порядку винними у вчинені злочину, за умови настання в них соціального ризику чи за складних життєвих обставин.

Традиційно набуття правового статусу засудженого асоціюється з наявністю низки обмежень в усіх сферах суспільного життя. Водночас, відповідно до Конституції України 1996 року, засуджений користується всіма правами людини і громадянина, за винятком обмежень, які визначені законом і встановлені вироком суду (ч. 3 ст. 63) [8]. У коментарі до переглянутих Європейських в’язничних правил, прийнятих у 2018 році, зазначено, що позбавлення волі не означає, що засуджені автоматично позбавляються своїх політичних, громадянські, соціальних, економічних і культурних прав. Будь-які обмеження повинні бути визначені законом, їх доцільно застосовувати лише у разі, коли вони є необхідними для забезпечення порядку та безпеки в’язниці (п. 2) [9].

Чинним кримінально-виконавчим законодавством передбачено обмеження деяких особистих, економічних та політичних прав. Щодо блоку соціальних прав, то можемо констатувати, що на сьогодні, де-юре, засуджені до позбавлення волі користуються цими правами нарівні із загальними суб'єктами суспільних відносин, водночас, де-факто, на практиці вказана категорія громадян під час реалізації соціальних прав стикається з низкою бюрократичних перепон та законодавчих колізій.

У сучасних умовах правове регулювання соціальних прав засуджених представлено системою міжнародних та національних нормативно-правових актів.

Значна увага щодо належної реалізації соціальних прав засудженими приділяється в Мінімальних стандартних правилах поводження з в'язнями, де передбачено таке:

- хворих в'язнів, які потребують послуг спеціаліста, необхідно переводити до особливих закладів або ж у цивільні лікарні. Тюремні лікарні повинні мати обладнання, установки й ліки, необхідні для належного медичного догляду за хворими та для їх лікування, а також достатньо кваліфікований персонал (п. 22.2); 
- усі засуджені в’язні повинні працювати відповідно до їхніх фізичних та психічних здібностей, засвідчених лікарем (п. 71.2);

- на в’язнів необхідно покладати роботу, достатню для того, щоб заповнити нормальний робочий день (п. 71.3);

- за свою працю в'язні повинні отримувати справедливу винагороду в межах певної системи (п. 76.1) тощо [10].

У площині курсу України стати повноправним членом європейської спільноти, особливої уваги в частині правового регулювання соціальних прав засуджених заслуговують Європейські пенітенціарні правила. Змістовний аналіз зазначеного документу свідчить про наявність у ньому низки норм, які прямо чи опосередковано регулюють соціальні права засуджених, зокрема:

- якщо (як виняток) діти до 18 років утримуються в пенітенціарних установах для дорослих, адміністрація мусить забезпечити в додаток до послуг, які надаються всім ув'язненим, аби малолітні ув'язнені мали доступ до соціальних та інших послуг (п. 35.1);

- адміністрація пенітенціарних установ мусить забезпечувати охорону здоров'я всіх ув'язнених цих установ (п. 39);

- ув'язнені мусять мати доступ до медичних послуг, котрі надаються у країні, без дискримінації за ознакою їхнього правового становища (п. 40.3);

- медичні послуги в пенітенціарних установах мусять бути спрямовані на виявлення та лікування фізичних та психічних хвороб або дефектів, на які можуть страждати ув’язнені (п. 40.4) тощо [11].

На національному рівні першоджерелом правового регулювання соціальних прав засуджених є Конституція України. Як справедливо наголошує М.М. Яцишин, засуджений хоч і відрізняється за своїм правовим статусом від інших громадян, він усе ж залишається правоздатним та дієздатним громадянином, суб’єктом обов’язків і прав, гарантованих Конституцією України та іншими законами, котрі визначають правовий статус громадян України [12, с. 130-131].

Зокрема, ст. 46 передбачено, що громадяни мають право на соціальний захист, який охоплює право на забезпечення їх у разі повної, часткової або тимчасової втрати працездатності, втрати годувальника, безробіття з незалежних від них обставин, а також у старості та в інших випадках, передбачених законом. У ст. 48 зафіксовано, що кожен має право на достатній життєвий рівень для себе і своєї сім’ї, що передбачає достатнє харчування, одяг, житло. У ст. 49 - кожен має право на охорону здоров'я, медичну допомогу та медичне страхування [8].

Важливим законодавчим актом щодо належного правового регулювання та забезпечення соціальних прав осіб, засуджених до позбавлення волі в Україні, $е$ Кримінально-виконавчий кодекс України (далі - КВК), який закріплює концептуальні засади діяльності щодо реалізації політики у сфері виконання кримінальних покарань в Україні. КВК України визначає сформульовані та закріплені на конституційному рівні основні принципи забезпечення соціальних прав засуджених осіб, закріплює основні засади правового статусу засуджених, гарантій захисту їх прав, законних інтересів та обов’язків [13]. 
Доцільно зауважити, що до 2014 року засуджені були обмежені в реалізації права на пенсійну виплату, що було прямим порушенням конституційного права засуджених на соціальний захист.

Законом України «Про внесення змін до Кримінально-виконавчого кодексу України щодо адаптації правового статусу засудженого до європейських стандартів» указаний кодекс було доповнено статтею 122 [14]. Зазначеним Законом були внесені зміни й доповнення в більш, ніж 40 статей КВК України [13], а окремі статті чи частини статей було викладено в новій редакції.

Головні моменти щодо соціальних прав засуджених у цьому нормативно-правовому акті зводяться до такого:

1) у новій редакції була викладена ч. 2 ст. 7 КВК України, в якій зазначено, що засуджені користуються всіма правами людини та громадянина, передбаченими Конституцією України, за винятком обмежень, визначених КВК України, законами України і встановлених вироком суду. У початковій редакції цієї частини про норми Конституції України чомусь забули;

2) ст. 7 КВК України була доповнена частиною п'ятою, в якій вказано, що дискримінація засуджених за ознаками раси, кольору шкіри, політичних, релігійних та інших переконань, статі, етнічного та соціального походження, майнового стану, місця проживання, за мовними або іншими ознаками забороняється, що цілком узгоджується з Основним Законом;

3) засуджені, які відбувають покарання у виправних колоніях мінімального рівня безпеки з полегшеними умовами тримання і працюють, отримали право на щорічний короткочасний виїзд за межі колонії тривалістю 14 календарних днів (ч. 4 ст. 111 КВК України);

4) засуджені жінки, які мають дітей, отримали право проживати з ними в будинках дитини при виправних колоніях до досягнення трьох років (ч. 3 ст. 141 КВК України);

5) доповнено ст. 122, відповідно до якої засуджені мають право на загальних підставах на державне пенсійне забезпечення за віком, по інвалідності, у зв'язку з утратою годувальника та в інших випадках, передбачених законом [14].

Вищезазначені новації у кримінально-виконавчому законодавстві беззаперечно сприяли розширенню соціальних прав засуджених.

Не менш важливим для забезпечення прав, зокрема соціальних, і свобод осіб, засуджених до позбавлення волі, є Закон України «Про соціальну адаптацію осіб, котрі відбувають чи відбули покарання у вигляді обмеження волі або позбавлення волі на певний строк», що визначає загальні засади соціальної адаптації осіб, які відбувають чи відбули покарання у вигляді позбавлення волі, засади участі в соціальній адаптації цих осіб підприємств, установ та організацій, об’єднань громадян, фізичних осіб, забезпечує правове регулювання відносин, спрямованих на реалізацію такими особами прав, передбачених Конституцією та законами України [15].

З огляду на закритість кримінально-виконавчої системи чинним національним законодавством передбачені дещо інші механізми реалізації соціальних прав для засуджених, аніж для громадян, які перебувають на свободі. У зв'язку із цим на 
практиці перші зіштовхуються з низкою процесуальних перепон. На обгрунтування нашої позиції проаналізуємо механізм реалізації пенсійних прав, які є складником соціальних, засуджених до позбавлення волі.

Відповідно до п. 1.4. Порядку подання та оформлення документів для призначення (перерахунку) пенсій відповідно до Закону України «Про загальнообов' язкове державне пенсійне страхування» (далі - Порядок) заява про призначення пенсії засудженим до позбавлення (обмеження) волі подається через представника, що діє на підставі виданої йому довіреності, посвідченої нотаріально, до органу, котрий призначає пенсію за місцезнаходженням установи виконання покарань. За бажанням зазначених осіб відповідні документи для призначення пенсії можуть подаватись ними безпосередньо відповідно до ст.ст. 60-1 та 122 Кримінально-виконавчого кодексу України [16].

Одночасно, поряд із вищезазначеною нормою продовжують діяти й інші положення. Відповідно до ч. 3 ст. 122 КВК України особа, яка під час відбування покарання набула право на пенсію, надає адміністрації виправного закладу клопотання про забезпечення необхідних умов для призначення їй пенсії за місцезнаходженням цього виправного закладу, зокрема, щодо виклику представників Пенсійного фонду України з метою подання у встановленому порядку необхідних документів безпосередньо особою, яка відбуває покарання, або представником особи, що відбуває покарання, за нотаріальним дорученням. Адміністрація виправного закладу не більш, ніж протягом 30 днів із дня реєстрації клопотання забезпечує зустріч засудженого із представником Пенсійного фонду України та всебічно сприяє належному оформленню й поданню ним відповідних документів або забезпечує умови для оформлення й подання необхідних документів через представника особи, яка відбуває покарання [13].

Наявність двох нормативно-правових актів різної юридичної сили, котрі регулюють механізм реалізації пенсійних прав засуджених, є суттєвим недоліком системи правового регулювання вищезазначеної групи прав, що призводить до ускладнення правозастосовної практики. Зокрема, на практиці часто виникають непорозумінні між працівниками Пенсійного фонду, адміністрацією установи покарань та власне засудженими до позбавлення волі щодо переваг застосування Порядку чи КВК.

У практичній площині залишається актуальною проблема щодо набуття права на пенсійну виплату засудженими. Для отримання пенсії на загальних умовах або для набуття права на ії призначення, окрім факту досягнення пенсійного віку, тобто 60 років, ще необхідна, відповідно до статті 26 Закону України «Про загальнообов'язкове державне пенсійне страхування», наявність страхового стажу визначеної тривалості [17], тобто особа повинна бути застрахованою в системі загальнообов'язкового державного соціального страхування.

Відповідно до ч. 1 ст. 122 КВК України засуджені до позбавлення волі, залучені до суспільно-корисної оплачуваної праці за строковим трудовим договором, підлягають загальнообов'язковому державному соціальному страхуванню [13]. Водночас на практиці трапляються непоодинокі випадки, за яких вищезазначена норма ігнорується адміністрацією установ виконання покарань. 
Загальнопоширеними є випадки, за яких адміністрація установи виконання покарань, залучаючи засудженого до праці, не укладають із ними строковий трудовий договір чи цивільно-правову угоду. Наявність таких порушень призводить до того, що цей період суспільно-корисної діяльності не зараховується до страхового стажу, та, як наслідок, зі свого боку, призводить до відсутності права на призначення страхової пенсії в солідарній системі загальнообов'язкового державного пенсійного страхування.

Попри зазначене, після звільнення з установи виконання покарань, за відсутності страхового стажу, засуджений матиме право на призначення допомоги по безробіттю в мінімальному розмірі.

У щорічній доповіді Уповноваженого Верховної Ради України із прав людини про стан дотримання та захисту прав і свобод людини і громадянина в Україні за 2018 рік зазначено, що протягом зазначеного року моніторинговими візитами було охоплено всі слідчі ізолятори та установи виконання покарань із функціями слідчих ізоляторів, де в межах реалізації національного превентивного механізму було виявлено типові порушення прав і свобод людини в установах, підпорядкованих Мін'юсту, які можуть кваліфікуватися як катування, жорстоке або таке, що принижує гідність, поводження або покарання: порушення права засуджених на працю та гідну їі оплату, необгрунтоване здійснення відрахувань із заробітку або іншого доходу засуджених до позбавлення волі тощо [18, с. 95].

Як показують численні результати моніторингових візитів до місць несвободи попередніх років, у межах реалізації національного превентивного механізму - порушення соціальних прав засуджених до позбавлення волі є загальнопоширеними.

На початку 2019 року представниками національного превентивного механізму було здійснено моніторинг Старобабанівської виправної колонії № 92 на Черкащині, де виявлено низку грубих порушень соціальних прав засуджених, а саме:

- медична допомога засудженим, які звернулись до медичної частини установи, надається через металеву решітку для забезпечення особистої безпеки медичного персоналу;

- порушення трудових прав засуджених (права на гідні умови праці, її належну оплату тощо).

Установлено, що кочегарами котелень гуртожитків для засуджених працюють засуджені, з якими не було укладено відповідні трудові договори або договори цивільно-правового характеру. Заробітна плата за виконану роботу засудженим-кочегарам упродовж опалювального сезону 2018-2019 року не нараховувалась. Навчання 3 користування котловим обладнанням та інструктаж із техніки безпеки не проводились; порушення прав осіб з особливими потребами - в установі утримується 33 засуджених з інвалідністю, зокрема близько 20 осіб, які мають проблеми з опорно-руховим апаратом. Через відсутність візків іншим засудженим доводиться носити зазначених осіб на руках [19]. Наявність таких грубих порушень національного законодавства на сучасному етапі розвитку суспільства $є$ неприпустимим.

Навесні 2019 року під час моніторингу Біленьківської виправної колонії № 99 у Запорізькій області, було виявлено відсутність належного обліку травматизму серед засуджених. Зокрема, у квітні вказаного року в цій установі трапився випадок 
травмування, який не відображений у відповідному журналі, а тому не проводилась перевірка за цим фактом [20].

Без належного оформлення травматизму та нещасного випадку фактично засуджений позбавляється, а в разі його смерті - відповідно члени сім'ї, на соціальні виплати із системи загальнообов'язкового державного соціального страхування.

Вищезазначені факти дають підстави стверджувати про порушення соціальних прав засуджених, передбачених ст.ст. 43, 46, 48, 49 Конституції України з боку адміністацій установ виконання покарань. Основним Законом установлено непорушність соціальних прав для громадян України, однак, як показує практика, через закритість кримінально-виконавчої системи засуджені фактично позбавлені можливості реалізовувати соціальні права належним чином.

Висновки. Проведене вище дослідження правового регулювання соціальних прав засудженими до позбавлення волі дозволяє констатувати, що, з одного боку, Україна має суттєві здобутки та позитивні результати у вищезазначеній сфері. Однак з іншого - на практиці й донині залишаються поширеними випадки масового нехтування та порушення відповідних прав щодо вищезазначеної категорії громадян.

\section{Jimepamypa}

1. Петровський П. Філософські основи методології державного управління. Ефективність державного управління : збірник наукових праць Львівського регіонального інституту державного управління Наиіональної академії державного управління при Президентові України. 2008. Вип. 14/15. С. 118-125.

2. Теорія держави і права : підручник / Ю.А. Ведєрніков та ін. 3-є вид. перероб. і доп. Дніпро : Дніпроп. держ. ун-т внутр. справ, 2016; Ліра ЛТД. 480 с.

3. Большой юридический словарь / под ред. А.Я. Сухарева. Москва : ИНФА-Москва, 2007. 858 с.

4. Левицька В. Теоретичні інтерпретації сутності поняття «соціальні права». Актуальні проблеми державного управління : зб. наук. пр. ОРІДУ. 2012. Вип. 3(51). С. 18-21.

5. Кримінально-процесуальний кодекс України: Кодекс від 13.04.2012 p. № 4651-VI. Відомості Верховної Ради України. 2013. № 9-10. Ст. 88.

6. Великий тлумачний словник української мови (з дод. і допов.) / уклад. і голов. ред. В.Т. Бусел. Київ; Ірпінь : ВТФ «Перун», 2005. 1728 с.

7. Чеботарьова Ю.А. Правовий статус засуджених до позбавлення волі : автореф. дис. ... канд. юрид. наук : 12.00 .08 . Київ, 2005. 22 с.

8. Конституція України : Закон України від 28.06.1996 р. № 254к/96-ВР. Відомості Верховної Ради України. 1996. № 30. Ст. 140.

9. Revised rules and commentary to Recommendation CM/REC(2006) 2 of the Committee of Ministers to Member States on the European Prison Rules. URL: https://rm.coe.int/pc-cp-2018-15-e-rev-3-epr2006-with-changes-and-commentary-08-10-18/16808е4ac1 (дата звернення: 20.05.2020).

10. Мінімальні стандартні правила поводження з в'язнями : Правила, Міжнародний документ від 30.08.1955. URL: http://zakon4.rada.gov.ua/laws/show/995_212 (дата звернення: 20.05.2020).

11. Європейські пенітенціарні правила: Рекомендація № R (2006) 2 Комітету Міністрів державучасниць. URL: https://zakon.rada.gov.ua/laws/show/994_032 (дата звернення: 20.05.2020).

12. Яцишин М.М. Історико-правові засади кримінально-виконавчої політики України : монографія. Луцьк : Волинський національний університет імені Лесі Українки, 2010. 440 с.

13. Кримінально-виконавчий кодекс України: Закон України від 11.07.2003. № 1129-IV. Дата оновлення: 04.11.2018. URL: https://zakon.rada.gov.ua/laws/show/112915 (дата звернення: 20.05.2020).

14. Про внесення змін до Кримінально-виконавчого кодексу України щодо адаптації правового статусу засудженого до європейських стандартів: Закон України від 08.04.2014 p. № 1186-VII. Відомості Верховної Ради України. 2014. № 23. Ст. 869. 
15. Про соціальну адаптацію осіб, які відбувають чи відбули покарання у вигляді обмеження волі або позбавлення волі на певний строк: Закон України від 17.03.2011 р. № 3160-VI. Відомості Верховної Ради України. 2011. № 38. Ст. 380.

16. Порядок подання та оформлення документів для призначення (перерахунку) пенсій відповідно до Закону України «Про загальнообов'язкове державне пенсійне страхування»: Постанова правління Пенсійного фонду України від 25.11.2005 р. № 22-1. Дата оновлення: 15.03.2019. URL: https://zakon.rada.gov.ua/laws/show/z1566-05 (дата звернення: 20.05.2020).

17. Про загальнообов'язкове державне пенсійне страхування: Закон України від 09.07.2003 р. № 1058-IV. Дата оновлення: 01.01.2019. URL: https://zakon.rada.gov.ua/laws/show/1058-15 (дата звернення: 20.05.2020).

18. Щорічна доповідь Уповноваженого Верховної Ради України з прав людини про стан додержання та захисту прав і свобод людини і громадянина в Україні за 2018 рік. URL: file://C:/Users/User/ Downloads/Report-2019\% 20(3).pdf (дата звернення: 20.05.2020).

19. У Старобабанівській виправній колонії № 92 на Черкащині медичну допомогу надають через решітку. URL: https://notorture.org.ua/2019/03/22/u-starobabanivskij-vipravnij-kolonii-92-nacherkashhini-medichnu-dopomogu-nadajut-cherez-reshitku/ (дата звернення: 20.05.2020).

20. Відбулись моніторингові візити до установ виконання покарань Запорізької області. URL: https://notorture.org.ua/2019/05/17/vidbulisja-monitoringovi-viziti-do-ustanov-vikonannja-pokaranzaporizkoi-oblasti/ (дата звернення: 20.05.2020).

\section{Анотація}

Шумна Л. П., Денисенко К. В., Бессараб А. С. Правове регулювання соціальних прав засуджених до позбавлення волі. - Стаття.

Проаналізовано переваги та недоліки сучасного стану правового регулювання соціальних прав засуджених до позбавлення волі. Визначено ознаки соціальних прав засуджених:

- гарантованість - соціальні права засуджених закріплені в національних та міжнародних нормативно-правових актах;

- вони слугують засобом задоволення життєвих потреб на рівні не нижчому, ніж розмір прожиткового мінімуму, встановленого законом;

- реалізуються в добровільному порядку, за відсутності примусу;

- серцевиною слугує наявність соціальних ризиків та/або складних життєвих обставин та/або страхового випадку, причому незалежно від часу їх виникнення - до ув'язнення чи після;

- обсяг соціальних прав засуджених, як правило, варіюється із тривалістю страхового стажу та розміру отримуваного заробітку;

- можуть реалізовуватись як на регулярній основі, так і на тимчасовій;

- фінансування витрат на реалізацію соціальних прав засуджених здійснюється за кошт Державного бюджету України та інших, не заборонених чинним законодавством, джерел.

Сформульовано поняття «соціальні права засуджених до позбавлення волі» як система прав, котрі закріплені в національних та міжнародних нормативно-правових актах, спрямовані на нейтралізацію складних соціально-життєвих обставин та/або забезпечення рівня життя в розмірі не менше прожиткового мінімуму за умови настання соціальних ризиків, а також належного функціонування людського організму громадян, які визнані в судовому порядку винними у вчинені злочину, під час настання в них соціального ризику чи складних життєвих обставин.

Результати моніторингових візитів до місць несвободи попередніх років у межах реалізації національного превентивного механізму дозволяють констатувати, що порушення соціальних прав засуджених до позбавлення волі на практиціє загальнопоширеними. Вищезазначені факти дають підстави стверджувати про порушення соціальних прав засуджених, передбачених ст.ст. 43, 46, 48, 49 Конституції України з боку адміністрацій установ виконання покарань. Основним Законом установлено непорушність соціальних прав для громадян України, однак, як показує практика, через закритість кримінально-виконавчої системи засуджені фактично позбавлені можливості реалізовувати соціальні права належним чином.

На основі дослідження правового регулювання соціальних прав засуджених до позбавлення волі встановлено, що, з одного боку, Україна має суттєві здобутки та позитивні результати у вищезазначеній сфері. 3 іншого - на практиці й донині залишаються поширеними випадки масового нехтування та порушення відповідних прав щодо вищезазначеної категорії громадян.

Ключові слова: правове регулювання, соціальні права, засуджені до позбавлення волі, ув'язнені, права людини. 


\section{Summary}

Shumna L. P., Denysenko K. V., Bessarab A. S. Legal regulation of social rights of prisoners to imprisonment. - Article.

The article is devoted to the analysis of the advantages and disadvantages of the current state of legal regulation of social rights of persons sentenced to imprisonment. The signs of social rights of convicts are determined:

- guarantee - social rights of convicts are enshrined in national and international regulations;

- they serve as a means of meeting the needs of life at a level not lower than the subsistence level established by law;

- are sold voluntarily, in the absence of coercion;

- the core is the presence of social risks and/or difficult life circumstances and/or the insured event, regardless of the time of their occurrence - before or after imprisonment;

- the scope of social rights of convicts, as a rule, varies with the length of insurance and the amount of earnings received;

- can be implemented both on a regular basis and temporarily;

- financing of expenses for realization of social rights of convicts is carried out at the expense of means of the State budget of Ukraine and other sources which are not forbidden by the current legislation.

The concept of social rights of persons sentenced to imprisonment is formulated as a system of rights enshrined in national and international regulations, aimed at neutralizing complex social and life circumstances and/or ensuring a standard of living at least the subsistence level in the event of social risks, and also the proper functioning of the human body of citizens who have been found guilty in court of a crime, in the event of social risk or difficult life circumstances.

The results of monitoring visits to places of detention in previous years in the framework of the implementation of the national preventive mechanism allow us to say that violations of social rights of persons sentenced to imprisonment are widespread in practice. The above facts give grounds to allege a violation of social rights of convicts under Art. 43, 46, 48, 49 of the Constitution of Ukraine by the administrations of penitentiary institutions. The Basic Law establishes the inviolability of social rights for citizens of Ukraine, however, as practice shows, due to the closed nature of the penitentiary system, convicts are effectively deprived of the opportunity to exercise social rights properly.

Based on a study of legal regulation of social rights of persons sentenced to imprisonment, it is established that, on the one hand, Ukraine has significant achievements and positive results in the above area. On the other hand, in practice, cases of mass neglect and violation of the relevant rights of the above-mentioned category of citizens remain widespread to this day.

Key words: legal regulation, social rights, sentenced to imprisonment, prisoners, human rights. 